Lukács Fruzsina ${ }^{1}-$ Sebö Tamás ${ }^{2}$

${ }^{1}$ Szent István Egyetem, Gazdaság- és Társadalomtudományi Kar, TTI, Pszichológia Tanszék

${ }^{2}$ Szegedi Tudományegyetem Életvezetési Tanácsadó Központ

\title{
Az egyetemi lemorzsolódás kérdőíves vizsgálata
}

Az egyetemi tanulmányok megszakitásának „költségei” igen magasak az érintett hallgató, a környezete, az intézmény, valamint a társadalom számára egyaránt. Ennek ellenére ez a probléma az egyetemi képzésben is egyre nagyobb mértékben jelentkezik, bár képzési területenként eltéró arányban. Tanulmányunkban egy olyan önértékeló kérdốves eljárás fejlesztési lépéseit mutatjuk be, amelynek

célja, hogy a döntés meghozatala elótt pontos képet adjon a hallgatónak kilépési szándéka okairól, és azokról a lépésekról, amiket tehet. Ez nem azt jelenti, hogy célunk lenne a hallgató „visszatartása”, azonban szeretnénk elérni, hogy döntése tudatos és informált legyen, akármi is lesz annak végeredménye.

A z Európai Unió (EU) stratégiai célkitüzései között szerepel mint oktatással kapcsolatos cél, hogy a korai iskolaelhagyók számát, a lemorzsolódást 10 százalék alá csökkentsék. A célkitüzés nem kifejezetten az egyetemista populációra vonatkozik. A lemorzsolódás vizsgálatát a különböző szakpolitikai dokumentumok más-más korcsoportra vonatkoztatva javasolják, azonban legkiemeltebben a korai iskolaelhagyás ('early school leaving') jelenségére koncentrálnak. A korai iskolaelhagyás azt jelenti, hogy a diákok a középfokú végzettség megszerzése nélkül hagyják el az iskolarendszert. Az EU-ban használt definíció szerint azokat a 18-24 év közötti személyeket tekintjük korai iskolaelhagyóknak, akik nem rendelkeznek befejezett középfokú végzettséggel, illetve szakképzettséggel (Molnár, 2012). A korai iskolaelhagyók aránya 2013-ban 11,8 százalék volt, ami romlást mutat az előző évek pozitív tendenciáihoz képest. Magyarország ezzel az eredménnyel az Európai Unió 28 országa közül a 21. helyen áll.

A társadalom iskolázottsága szoros összefüggést mutat a gazdasági versenyképességgel. Annak érdekében, hogy a másik „Európa 2020” stratégiai célt, a felsőoktatással rendelkezök arányának 40 százalékra növelését a 30-34 év közötti korosztályban (a javasolt magyar vállalás 27-30-33,3 százalék között változik, ld. Borbás, 2012) hosszú távon fenntarthassák vagy meg is haladhassák a tagállamok, elengedhetetlen, hogy a diákok befejezzék középfokú tanulmányaikat, illetve sikeresen teljesítsék egyetemi, főiskolai tanulmányaikat is.

A lemorzsolódás megoldása összefügg azzal az EU-s törekvéssel is, hogy minimálisra csökkentsék a NEET ('not in education, employment or training') fiatalok számát. Ennek a problémának a megoldására indították el az Ifjúsági Garancia Programot is, melynek ígérete szerint hosszú távon minden NEET-fiatal számára, aki az oktatásból, foglalkoztatásból 25 éves kora elött kiesik, négy hónapon belül biztosítani kell, hogy képzésben (oktatási rendszeren belül vagy tanfolyami keret között), önkéntes tevékenységben, gyakornoki munkában vagy munkavégzésben vehessen részt (Jackson, 2013). 
Általánosságban a lemorzsolódás azt jelenti, hogy az oktatást befejezett végzettség nélkül elhagyók számát vizsgáljuk. A lemorzsolódás eddig feltárt rendszerszintủ negatív hatásai a következők: ki nem használt anyagi ráfordítás (ösztöndíjak, egyéb állami támogatások), bevételtől való elesés (amit elérhettek volna azok a személyek, akik kiestek az oktatásból), valamint megemelkedett költségek állami szinten (azok segítésére, akik a munkaerőpiacról is kiszorulnak).

Az egyetemi lemorzsolódás kezeléséhez fontos, hogy lássuk, mennyire kiterjedt a probléma, és milyen okok állnak mögötte.

\section{A lemorzsolódási arány vizsgálata}

A lemorzsolódásban érintett hallgatók körének meghatározása nem könnyü módszertani feladat. Varga (2010) a diploma értékének tárgyalásáról szóló cikkében az időre diplomát nem szerzettek 45 százalékos arányát emeli ki, és szembeállítja azt az EU és az OECD 30 százalék körüli felsőoktatásból való kilépési arányával. Ugyanakkor az, hogy valaki nem végez időre, nem jelenti azt, hogy a későbbiekben ezt ne tehetné meg, esetleg ne válthatna iskolát. A szerző is kiemeli, hogy ezzel kapcsolatban megbízható adatok nem állnak a rendelkezésünkre. Horn (1998, idézi Molnár, 2012) négyéves kutatása alapján az látható, hogy amennyiben a hallgató sikeresen meg tud birkózni az első évben tapasztalt nehézségekkel, a lemorzsolódás veszélye csökken. A kutatásban az első évet követően nagy volt a kilépési arány (39 százalék), azonban azok, akik maradtak, folytatták tanulmányaikat, és szinte kivétel nélkül oklevelet is szereztek. Polónyi (2001) szintén az időre diplomát nem szerzettek arányát vette figyelembe a lemorzsolódás 1990-es években való alakulásáról készített számításaiban: 1997 és 2000 között az egyetemi, ötéves képzésből való lemorzsolódás mértéke 26 százalékról 19,2 százalékra csökkent, míg a fóiskolai, hároméves képzésben nem történt számottevő változás.

Nagy sajtóvisszhangot (pl. eduline.hu, $H V G$ ) kapott az ELTE kutatása a bolognai képzés első évfolyamának egyetemi előmeneteléröl. Az eredményeket az 1. ábra szemlélteti.

A vizsgálat során megállapították (ld. 1. ábra), hogy a tanulmányaikat 2006-ban megkezdő diákok többségének 2009-ben végeznie kellett volna. A vizsgálatról készített jelentés szerint (Helyzetjelentés 2010) a pszichológia, a kommunikáció és az andragógia alapszakosok mintegy kétharmada teljesítette sikeresen a követelményeket, ellentétben a programtervező informatikusokkal, ahol ez mindössze a hallgatók 3,83 százalékának sikerült. A kutatási eredmények alapján a végleges lemorzsolódás is meglehetősen nagy volt, a 2006-ban indult bölcsészeknél a hallgatók 20 százaléka esett ki a képzésböl, míg a természettudományi területen 30 százalék körüli, de volt, ahol ennél is több.

A Szegedi Tudományegyetemen a következő státuszadatokat használták az egyének tanulmányi pályájának leírására: (1) végzett (sikeres): teljesítette a kötelező modulokat vagy abszolutóriumot szerzett, (2) kilépett: tagozatváltó, szakváltó, más intézményben folytatja tanulmányait, (3) lemorzsolódott: fegyelmi eljárás, túl sok passzív félév, egyéb tanulmányi ok, például a költségtérítés nem vállalása miatt a képzésböl kizárták vagy a szakot leadta (ide tartoznak azok a hallgatók is, akik a felvételi félévében nem iratkoztak be), (4) folyamatban: a hallgató státusza nem megállapítható a vizsgált időszakban (Varga, 2015). „Problémás” státuszúnak tekinthetők azok a hallgatók, akikről a vizsgált időszakban nem áll rendelkezésre egyértelmüen értelmezhető adat, illetve azok, akik nem iratkoztak be a felvétel elnyerése után, hiszen esetükben nincs mód megismerni a döntés okát (illetve az is előfordulhat, hogy tanulmányaik megkezdését „csak” késleltetik, így valójában nem is kellene lemorzsolódottaknak tekinteni őket). Így az egyetemek által készített statisztikák valójában a lemorzsolódás valós értékétől némileg eltérő adatokat tartalmazhatnak. 


\begin{tabular}{|c|c|c|c|c|c|}
\hline \multirow[t]{2}{*}{ Szak } & \multirow{2}{*}{$\begin{array}{l}\text { Beirattogott } \\
\text { hallgatot } \\
\text { szama, 2006 }\end{array}$} & \multicolumn{2}{|c|}{ otrevelet szerezter: } & \multirow{2}{*}{$\begin{array}{l}\text { Szakon maradt } \\
\text { nallgatok zote } \\
\text { etoo felereces) }\end{array}$} & \multirow{2}{*}{$\begin{array}{l}\text { Lemor- } \\
\text { zsolodtak } \\
(\theta)\end{array}$} \\
\hline & & $\begin{array}{l}2009 \\
(\%)\end{array}$ & $\begin{array}{l}2010 \\
(\%)\end{array}$ & & \\
\hline Pszichológia & 166 & 67,47 & 3,61 & 21,08 & 7,84 \\
\hline Icomm unikảció és médiatudomảny & 72 & 66,6 & 4,17 & 19,44 & $9, n$ \\
\hline Magyar & 311 & 46,92 & 2,84 & 30,81 & 19,52 \\
\hline Torténelem & 181 & 45,3 & 3,31 & 30,39 & 21 \\
\hline szabad bólószet & 167 & 42,51 & 3.59 & 38.32 & 15,58 \\
\hline Társadalmi tanuImànyolt & 180 & 41,11 & 2,78 & 32,22 & 23,89 \\
\hline Fóldtudományi & 163 & 40,49 & 0 & 26,38 & $33, \mathrm{~B}$ \\
\hline 6vodapedagógus & 97 & 39,18 & 3,09 & 21,65 & 36,08 \\
\hline Germanisztilla & 176 & 30,11 & 1,14 & 45,45 & 23,3 \\
\hline Politologia (jogi tar) & 99 & 29,29 & 3,03 & 45,45 & 22,23 \\
\hline Földrajz & 123 & 26,83 & 1,63 & 47,97 & 23,57 \\
\hline I6rayezettan & B9 & 20,86 & 3,6 & 47,48 & 28,06 \\
\hline Anglisztilita & 250 & 20,8 & 4,4 & 50 & 24,8 \\
\hline Matematika & 228 & 18,42 & 2,19 & 46,49 & 32,9 \\
\hline Keleti nyelvelt és kultúrált & 138 & 18,12 & 0 & 53,62 & 28.26 \\
\hline Kémia & 120 & 17,5 & 0 & 36,67 & 45,83 \\
\hline Fizilla & B9 & 15,11 & 0 & 41,73 & 43,16 \\
\hline Biológia & 251 & 10,36 & 1,2 & 52,99 & 35,45 \\
\hline Programtervezö informatilus & 496 & 3.83 & 2,02 & 33.47 & 60,68 \\
\hline
\end{tabular}

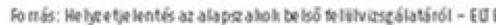

1. ábra. Az időre végzettek, a szakon maradók és a lemorzsolódottak aránya az ELTE 19, három évig tartó szakjainak esetében (forrás: eduline.hu)

A Szegedi Tudományegyetemen a 2009/2010-es tanévben tanulmányaikat megkezdő hallgatók státuszait vizsgálták. A lemorzsolódók aránya az alap- és osztatlan képzések esetén jelentős (36-38 százalék) volt, így elmondható, hogy ezzel a problémával mindenképp foglalkozni kell egyetemi szinten. A lemorzsolódottak aránya képzési területenként eltér, a legmagasabb arány az alap- és osztatlan képzésben az informatika (52 százalék) képzési területen volt, ezt követi a természettudományi (47,7 százalék), a hitéleti (46,4 százalék) és a müszaki (41,5 százalék) terület. Az egyetemi átlaghoz (36-38 százalék) hasonló arány mutatkozik az agrár és a bölcsészettudományi területen. Az átlag alatt, de 30 százalék közeli lemorzsolódással hét képzési terület jellemezhető. A legalacsonyabb lemorzsolódás az alap- és az osztatlan képzésben a közigazgatási és a müvészeti területekre jellemző. Mesterképzésben és szakirányú továbbképzéseken jóval alacsonyabb a lemorzsolódási arány (14-17 százalék), azonban nyolc képzési terület e fölött az átlag fölött teljesített. A hitéleti, informatika, orvos- és egészségtudomány, müszaki és gazdaságtudományok képzési területeken a lemorzsolódás aránya 20-30 százalék közötti.

Képzési szinttől függetlenül magas lemorzsolódás jellemezte a következő képzési területeket: agrár, müszaki, informatika, orvos- és egészségtudomány, hitélet. A képzési területek sora alapján az ezekhez a területekhez tartozó képzések és foglalkozások többségének presztízse magas, illetve azok jó munkaerő -piaci kimenettel párosulnak. A lemorzsolódás oka így - valószínüleg - nem ezeken a területeken keresendő, bár nyitott kérdés, hogy a hallgatók milyen mértékben vannak tisztában választott szakjuk munkaerő-piaci sajátosságaival. Képzési szinttől függetlenül alacsony lemorzsolódás jellemzi a következő képzési területeket: művészet, pedagógusképzés, bölcsészettudomány. 
Tanulságként az fogalmazódott meg, hogy olyan képzések esetén átlag alatti a lemorzsolódás, ahol a felvételi eljárásban van lehetőség erősen szelektálni a jelentkezőket ( $\mathrm{pl}$. müvészet, osztatlan építész, közigazgatási, rendészeti, katonai képzések), és/vagy ahol az oktatók pedagógiai szakértelemmel rendelkeznek (Varga, 2015).

\section{A lemorzsolódás okai}

Molnár (2012) az amerikai Tinto és Bean vizsgálatai alapján tárgyalja a felsőoktatásból való kilépés lehetséges okait. A szerzők évtizedekig kutatták a jelenséget, és arra jutottak, hogy az egyetemi tanulmányok megszakítása a szocializációs folyamat megszakítását is jelenti. Bean (1985, idézi Molnár, 2012) korai elmélete a családi és az intézményi támogatást és anyagi segítséget helyezi a középpontba. A jelenségre ható tényezőket a következőképp csoportosította: háttérváltozók, szervezeti változók, akadémiai tényezők, szociális tényezők, környezeti változók, valamint attitüdök, szándékok és pszichológiai folyamatok.

A háttérváltozók között a szülői támogatást, azok jövedelmét, a középiskolai sikeres tanulmányi előmenetelt, főiskolai előkészítő elvégzését és a baráti társasággal rendelkezést sorolja fel. A szervezeti változók között találhatók az egyetem szintjén megjelenő pénzügyi támogatások, a tájékoztatási programok, szabályozások, az egyetemi szervezetek bevonódása a tanulmányokkal kapcsolatos döntéshozatalba, az adminisztrációs folyamatok és a személyzet hozzáállása a diákokhoz. Az akadémiai tényezők között szerepelnek a tanácsadási szolgáltatások, a készségfejlesztő programok, az egyetemi erőforrások (pl. számítógépek), a hiányzások aránya, a jogbiztonság és az egyetemi integrációs törekvések. A szociális tényezők körébe tartozik a közeli barátok megtartásának képessége, a szakmai kultúra, az egyetemi csoporttal való azonosulás, valamint a társadalmi integráció. A környezeti változók ismét a család szerepét hangsúlyozzák: a folyamatos szülői támogatás, a pénzügyi források és a családi kötelezettségek. A pszichológiai folyamatok és attitüdök közül Bean a következőket emeli ki: énhatékonyság, önfejlesztés képessége és önbizalom, önellenőrzés, tanulási stratégiák, motiváció, stressz, elidegenedés és kitartás.

A brit egyetemeken 2001-ben úgy becsülték, hogy hatból egy hallgató nem teljesíti a képzési programot, ennek következtében igen sok pénzbeli és emberi erőfeszítés megy kárba évről évre. Ez a veszteség sok szinten megjelenik: az adminisztrációs szintektől kezdve az oktatói létszám aránytalanságán keresztül a csoportos munkafolyamatok nehézkességén át az évfolyamon uralkodó hangulatig. Nem beszélve arról, hogy a lemorzsolódó diákok rossz hírét viszik intézményüknek. A piaci-kereskedelmi tapasztalatok szerint akkor, ha egy vásárló csalódik egy cég szolgáltatásában, azt legalább 9-10 másik embernek mondja el, ezzel őket is befolyásolva (Sonnenberg, 1990, idézi Bennett, 2003). Tehát egy olyan intézmény, amely kevésbé képes megtartani diákjait, hosszú távon a hírnevét veszélyezteti.

A képzési programból való kilépés a diákok részéröl lehet kényszerdöntés vagy egy önkéntesen meghozott döntés. Kényszerhelyzetről akkor beszélünk, ha valakinek túl sok elmulasztott vizsgája gyülik össze, súlyos betegségben szenved, esetleg a családi szerepvállalása növekedik meg vagy nincs forrása a további tandíjra (Medway és Penney, 1994). Az önkéntes döntés egy tudatos döntés eredménye, aminek oka lehet, hogy a hallgató nem találja értékesnek a szakot, nem jön ki a csoporttársaival és tanáraival, nem érdeklik az oktatott tantárgyak. Az ilyen lemorzsolódás - a hallgatók saját bevallása alapján - ritka. Az UK FE egyetemen a 13 százaléknyi lemorzsolódónak 80 százaléka jelezte, hogy anyagi, családi vagy munkavállalási okokból tett le a diploma megszerzéséről, és csak 10 százalék vallotta azt, hogy a képzési program minősége vagy gyenge tanulmányi 
teljesítménye ösztönözte erre. Ezzel egybehangzóan azt találták, hogy a szerényebb anyagi háttérrel rendelkező diákok nagyobb mértékben vannak kitéve a lemorzsolódás veszélyének. A brit állam különböző ösztöndíjak és tanulmányi hitelek segítségével igyekszik segíteni, változtatni ezen a helyzeten. Az anyagi nehézségekre való természetes reakció a részmunkaidős munkavállalás, ami egyre inkább „konfliktusba” kerül a tanulmányi előmenetel színvonalával. Egy másik fontos tény, hogy az anyagi nehézségek miatti takarékoskodási kényszer több dologtól is megfosztja a diákot. Például nehezebben tud integrálódni az órákon kívüli informális életbe, kevesebbet tud napi utazásra költeni, akár városon belül is. Így, szándékán kívül, izolálja magát az egyetemi szociális hálótól, és elvész a valahová tartozás élménye. Az is előfordul, hogy valamilyen tankönyvtől, jegyzettől vagy egyéb segédeszköztől esik el anyagi forrás hiánya miatt.

Bizonyos vizsgálatok rámutatnak más lemorzsolódásra ható tényezőkre is. Vannak vizsgálatok, amiket olyan mintán végeztek, ahol a diákok szocio-ökonómiai státusza közel azonos volt, azonban a lemorzsolódás mértéke az egyes szakok között mégis 3-56 százalék között ingadozott (Davies, 2000). Megfigyelhető, hogy az anyagi és a személyes nehézségek akkor vannak igazán hatással az egyetemi karrierre, ha a diák elégedetlen az oktatás és az egyetemi közeg minőségével, esetleg unalmasnak tartja a képzési programot. A magas színvonalú oktatás, a képzéssel való elégedettség és a diákok igényihez való alkalmazkodás fontos bejósló tényezői a későbbi lemorzsolódásnak. A tipikus lemorzsolódó az a férfi, aki 21. évét betöltve kezdi meg tanulmányait, és nem kollégiumban vagy egyéb egyetemi közegben él (Martinez, 2001, idézi Bennett, 2003). Kvalitatív vizsgálatok alapján a tanulmányok megszakításának okai föként ezek: (1) az egyetemi oktatásra való felkészületlenség, (2) a szükséges kompetenciák hiánya, (3) az egyéni érdeklődés és egyéb tényezők változása, (4) a jól fizető munka vonzereje, (5) a képzéssel való elégedetlenség. A képzéssel való elégedetlenség több tőről fakad. Oka lehet a nem megfelelően strukturált, unalmas oktatás, a rossz csoportlégkör, a helytelenül összeállított órarend, illetve a tanulási stílusukban nem illeszkedő tanuló és oktató (Bennett, 2003).

Egy másik kutatás (Tinto, 1993, idézi Bennett, 2003) szerint a tudományos-szakmai és szociális integráltság a két kulcstényezője a diákok képzésben tartásának. A szakmai identitást az adja meg, hogy a diák miként éli meg tanulmányi teljesítményét. Érzékeli-e, hogy tanulmányai során fejlődik, és oktatója elkötelezett a minőségi tudásátadás iránt. A szociális integráltság az egyéni kapcsolatok minőségén múlik. Lényeges elem a szakon, évfolyamon jelen lévő diákok jó viszonya, illetve az, hogy az oktatók és egyéb személyzet mennyire megközelíthető, barátságos (Saenz, 1999, idézi Bennett, 2003). A tanulási stílus és egyéb egyetemi teljesítményhez kapcsolódó kompetenciák szintén hatással lehetnek a lemorzsolódásra, és a szociális integráltság fogalmi keretében értelmezhetők (Heath és mtsai, 1991). Ezek lehetnek tanulási szokások és stratégiák, a jegyzetelés és annak feldolgozása, a vázlat- és esszékészítés, a tanulócsoportok előnyeinek kihasználása. A tanulmányait megszakító hallgató jellemzően mindkét integrációs szintéren nehézségekkel küzd. A döntő változó a lemorzsolódás terén, hogy a hallgató mennyire van elkötelezve az „egyetemi tapasztalatszerzésnek”. A honvágynak és a folyamatra való egyéni ráhatásnak szintén szerepe van. Egyéb faktor lehet a családi vagy más támogatói források megléte. Ezeknek a támogató személyeknek nem kell feltétlenül maguknak is a felsőoktatásban jártasnak lenniük.

A képzés kiválasztásakor kapott pályaorientációs konzultáció is nagy szerepet játszhat az egyetemi tanulmányok végigvitelében. Amennyiben egy diák késve kezdi meg az adott félévet vagy kurzust, az szintén nagyobb eséllyel morzsolódik le a félév folyamán. Külön kiemelendő tényező a képzőhely érzékelt hírneve, presztízse és az intézmény „megtartó ereje” közötti kapcsolat, bár ez statisztikailag eddig nem igazolt (Davies, 
2000, idézi Bennett, 2003). A hírnévnek különösen az első időkben van jelentősége, amikor a diák még nem tudja értékítéletét saját tapasztalataira helyezni. A diáktársak negatív hatása szintén eredményezhet lemorzsolódást, akárcsak a magányosság és az izoláltság érzése (Bennett, 2003).

\section{A kérdő́v létrehozásának folyamata}

A lemorzsolódást vizsgáló kérdőívünket Bennett (2003) empirikus kutatáson alapuló elméleti modelljére alapoztuk. A jobb megértés érdekében saját önértékelő kérdöívünk bemutatása előtt röviden összefoglaljuk ennek a vizsgálatnak a menetét és főbb eredményeit.

Bennett (2003) kutatásában 377 alsóbb éves egyetemista vizsgálatával tesztelte a lemorzsolódás elméleti modelljét. Azon a gazdasági egyetemen, ahol a vizsgálatot végezte, abban az évben 28 százalék volt a lemorzsolódási arány, ami jóval felette volt az országos 16 százaléknak. A lemorzsolódás komplex és multidimenzionális problémáját egy hipotetikus útvonalmodell keretében tesztelte és az eredményeknek megfelelően módosította. Az elkötelezettséget Meyer és munkatársai (1993) tízitemes skálájával mérték. Az elégedettséget Oliver (1993) tanórával való elégedettséget mérő hat itemes skálájával vizsgálták. Ezen felül három itemet adtak hozzá a skálához az egyetem informatikai ellátottságával, könyvtárával és a környezettel való elégedettséggel kapcsolatban. Az egyetem hírnevével kapcsolatban egyetlen direkt kérdést tettek fel: „A szakomnak az XY Egyetemen jó híre van.”. Külön rész foglalkozott a diákok tanárral kapcsolatos elégedettségével: mennyire gondolták segítőkésznek, jól felkészültnek, kíváncsinak. Nyolc item vizsgálta a diákok kapcsolatát a csoporttársaikkal, a személyzettel, valamint azt, hogy mennyire könnyen kötnek kapcsolatot. A tanulmányokkal kapcsolatos elköteleződést 5 item segítségével mérték. A tanulási szokásokat öt itemmel vizsgálták (Stoynoff, 1996). Az önbecsülést O’Guinn és Faber (1989) alapján a saját képességekbe vetett bizalom mentén vizsgálták. A motivációt Bennett és Kottasz (2001) alapján négy itemmel mérték, a három, családi támogatással kapcsolaAz eredmények azt mutatták, hogy a legerốsebb hatást a döntésre az anyagi nehézségek gyakorolták. Továbbá a pénzügyi nehézségeknek erốs moderáló hatásuk volt az alacsony szintú elkötelezódésen és a rossz tanulmányi eredményeken keresztül arra a döntésre, hogy kilépjen a személy. A második legerósebb direkt hatás a külsó, személyes problémák köre. Az alacsony

önbecsülés szignifikánsan moderálta a pénzügyi nehézségek és az alacsony teljesítmény hatását a kilépésre. Azok a diákok, akiknek alacsony volt az önbecsülésük, nagyobb valószinúséggel hagyták abba a tanulmányaikat, ha pénzügyi nehézségeik voltak, vagy ha rosszul teljesitettek az egyetemen. tos itemet Saenz és munkatársai (1999) munkája alapján hozták létre. Mindezeket a változókat ötfokú Likert-skálán kellett megítélni. Továbbá rákérdeztek más változókra is, például életkor, utazás az egyetemre, hetente munkával töltött idő, a szülői hozzájárulás mértéke a tandíjhoz, a szülők jártak-e egyetemre. 


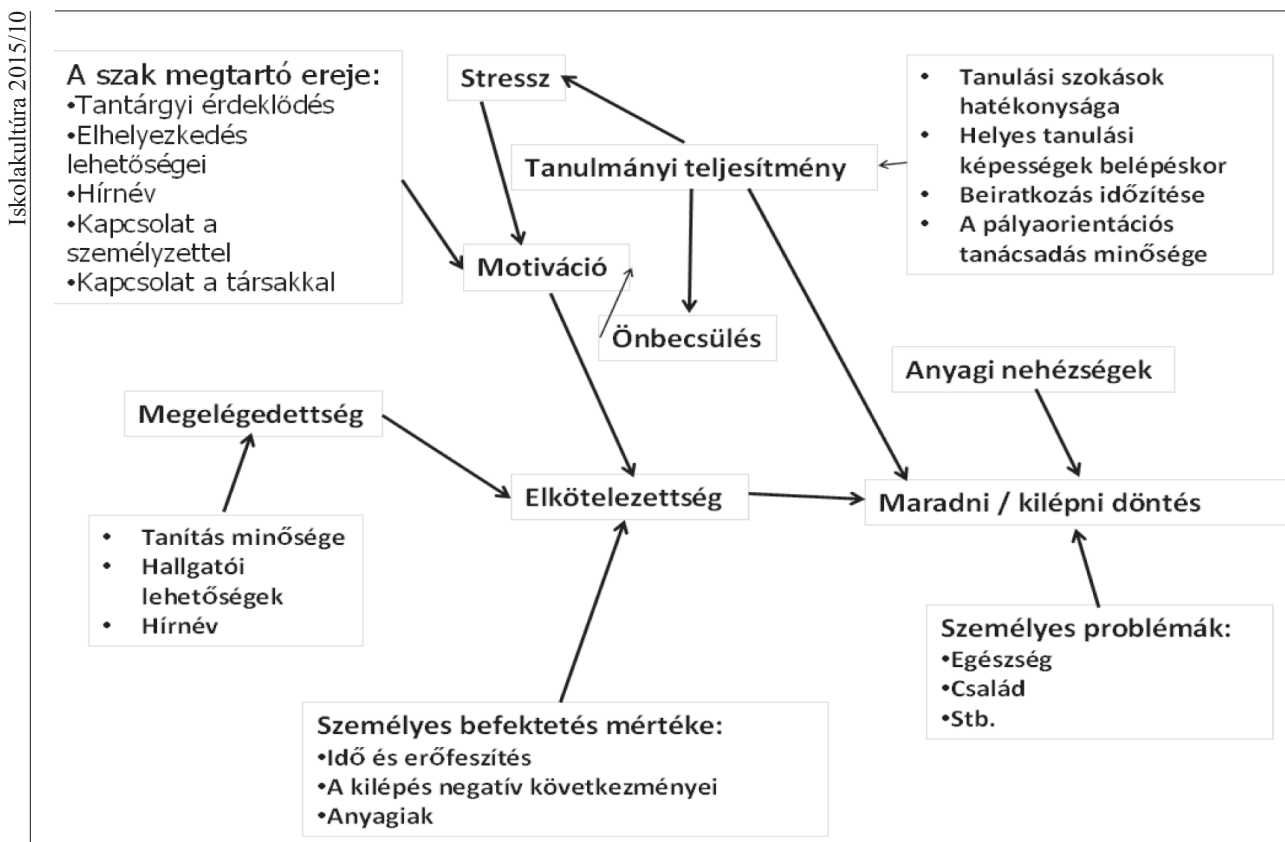

2. ábra. Bennett (2003) útvonalmodellje az egyetemről való kilépéssel (,,maradni/ kilépni döntés”) kapcsolatban

Az útvonalmodell felállítása előtt a változókat faktoranalízisnek vetették alá. A modell felállításához hat függő és 17 független változót használtak. A modell pszichometriai mutatói meggyőzőek ( $\mathrm{GFI}=0,901, \mathrm{AGFI}=0,888, \mathrm{RMSE}=0,031, \mathrm{P}=0,878)$. Az útvonalmodellt a 2. ábra mutatja.

Az eredmények azt mutatták, hogy a legerösebb hatást a döntésre az anyagi nehézségek gyakorolták. Továbbá a pénzügyi nehézségeknek erős moderáló hatásuk volt az alacsony szintű elköteleződésen és a rossz tanulmányi eredményeken keresztül arra a döntésre, hogy kilépjen a személy. A második legerösebb direkt hatás a külső, személyes problémák köre. Az alacsony önbecsülés szignifikánsan moderálta a pénzügyi nehézségek és az alacsony teljesítmény hatását a kilépésre. Azok a diákok, akiknek alacsony volt az önbecsülésük, nagyobb valószínüséggel hagyták abba a tanulmányaikat, ha pénzügyi nehézségeik voltak, vagy ha rosszul teljesítettek az egyetemen.

Saját kérdőívünk kidolgozása során arra törekedtünk, hogy a kidolgozott önértékelő kérdőív amellett, hogy tudományosan megalapozott legyen, gyakorlati haszonnal is bírjon a kitöltő számára. A kitöltőknek ötfokú Likert-skálán (5=teljesen igaz rám - 1=egyáltalán nem igaz rám) kell megítélni a 80 állítás mindegyikét. A skálák - Bennett (2003) alapján - a következők (minden skála esetén egy mintaitem is olvasható):

1. Motiváció („Erős a motivációm, hogy sikeres legyek a szakomon.”).

2. Tanulmányi teljesítmény („Rendszeresen átnézem a tananyagot, sokat ismétlek.”).

3. Elkötelezettség (,Akkor sem hagynám abba a tanulmányaimat, ha a diploma megszerzése nélkül ajánlanának nekem egy kiváló és jól fizető állást.").

4. Kapcsolatok (,Sokszor érzem magányosnak magam a problémáimmal.”).

5. Önbecsülés (,Mindent egybevetve hajlamos vagyok arra, hogy tehetségtelen, sikertelen embernek tartsam magamat."). 
6. Elégedettség („Az egyetemi könyvtárban mindent megtalálok, amire szükségem lehet.").

7. Stresszkezelés („Egy kis izgalom még jót is tesz vizsga előtt.”).

8. Anyagiak (,Anyagi gondjaim miatt korlátozottak a lehetőségeim.”).

9. Külső (személyes) problémák kezelése („A családomban lévő problémák miatt kevesebb időm jut az egyetemre koncentrálni.").

10. Információk („Ismerem azokat a foglalkozásokat és munkaköröket, amelyeket a diploma megszerzésével betölthetek.”).

Az adatgyüjtés jelenleg zajlik. A kérdőív pszichometriai mutatóiról és az eredményekről egy későbbi tanulmányban számolunk be.

\section{Összegzés, gyakorlati megfontolások}

Tanulmányunkban bemutattuk a lemorzsolódás mérését, lehetséges okait, valamint bemutattuk a lemorzsolódással kapcsolatos önértékelő kérdőív fejlesztési folyamatát. Mindezek alapján általánosságban megfogalmazhatóak olyan gyakorlati tanácsok, amelyek jó eséllyel csökkentik a lemorzsolódást.

A tanulmányok finanszírozásának kapcsán fontos, hogy a diák átlássa, milyen ösztöndíjak, tanulmányi hitelek közül választhat. Adott esetben hasznos lehet egyetemi munkaerő közvetítése, ahol a diák olyan munkát találhat, ami időbeosztásában rugalmasan alakítható egyetemi kötelezettségeihez. Ahol lehetőség és kapacitás van rá, érdemes kapcsolatot tartani olyan munkáltatóval, amelyik a tanulmányokhoz kapcsolódó tevékenységet végez, és így alkalmas lehet szakmai tapasztalatszerzésre. A költségek csökkentésének szempontjából meghatározó kérdés a kollégiumi lakhatás lehetősége.

Az egyetemen és a képzésen kötődő kapcsolatok minőségére is érdemes hangsúlyt fektetni. A tanulmányi ügyek akadálymentesítésének érdekében fontos az adminisztrációs teendők világossá tétele, és jól funkcionáló kapcsolat kialakítása a kiszolgáló személyzettel. Amennyiben ezen információs csatorna jól müködik, a jelentkező nehézségek könnyen orvosolhatóvá válnak.

Lényeges elem a képzésben oktatók szakmai tudása elméleti és gyakorlati szinten egyaránt, valamint a tudásátadás iránti elkötelezettsége és kompetenciája. Ez a mintaadás komoly elköteleződésre sarkallja a diákot, így biztosítva a megelégedettséget és a folyamatosan fenntartott motivációt a tanulmányok iránt. Ezzel párhuzamosan érdemes figyelni az oktatók megközelíthetőségére, vagyis hogy kialakulhasson egy személyesebb jellegü tanár-diák viszony.

A szociális integráltság kapcsán fontos a képzéshez kapcsolódó informális terek és események szervezése azok szakmai és emberi aspektusának kiemelésével. Ez elősegítheti a hallgatók közötti improduktív rivalizáció minimálisra csökkentését, valamint erősíti a szakmai identitás létrejöttét. A hallgatók tanulásmódszertani fejlesztése a kezdetektől fogva kiemelten fontos: a tanulási stílus felmérésétől és fejlesztésétől kezdve a tanulási szokások és stratégiákon át az egyéni és csoportos feladatmegoldásig. Ezen a téren akár a képzés jellegzetességeihez igazodva is érdemes lehet érzékenyíteni-fejleszteni a hallgatókat. Ha lehetőség van rá, a tanterv ergonomikus összeállítása szempontjából lényeges lehet, hogy egy féléven belül az órák heti szintü eloszlása kedvezzen a hallgató időbeosztásának, például a kötelező kurzusok megfelelő struktúrában jelenjenek meg a szorgalmi időszak heteiben.

A félév kezdetén érdemes hangsúlyt fektetni a hallgató által felvett kurzusok első óráin való jelenlétre. Ekkor van lehetőség arra, hogy a félévre tervezett tanulmányi munka teljesítésének feltételei a hallgató és az oktató részéről is tisztázottak legyenek. Erre javasolt 
írásbeli szerződést kötni, ami által a hallgató számára tervezhetővé válik a félév tanulmányi terhelése, ehhez igazítani tudja életvezetésének egyéb területeit.

Az életpálya tervezésének szempontjából fontos lehet, hogy a diák számára folyamatosan árnyalódjon a kép, hogy miként tudja hasznosítani egyetemen megszerzett kompetenciáit a későbbiekben. Erre a pályaszocializációs órák lehetnek a legalkalmasabbak. Képzéstől függetlenül minden karon ügyelni kell arra, hogy a mindenkori segítségkérés lehetőségei és útvonalai világosak legyenek a hallgató előtt. Tisztázandó, hogy miként és milyen keretek között kaphat egészségügyi és mentálhigiénés ellátást, hova fordulhat életvezetési tanácsért, milyen segítséget kaphat karriertervezési vagy akár hitéleti kérdésekben. A tanulmányi előmenetellel összefüggő kérdésekben a hallgatónak mint egyetemi polgárnak tisztában kell lennie jogaival, kötelezettségeivel és lehetőségeivel. Ezen információk megléte sokszor kulcsfontosságú egy olyan dilemma eldöntésében, amikor a tanulmányok folytatása vagy megszakítása a tét.

\section{Irodalomjegyzék}

Bennett, R. (2003): Determinants of undergraduate student drop out rates in a University Business Studies Department. Journal of Further and Higher Education, 27. 2. sz. 123-141.

\section{DOI: $10.1080 / 030987703200065154$}

Borbás László (2012): Európai elvárások - magyar válaszok. Az Európa 2020 stratégia üzenete Magyarországnak. 2015. 06. 08-i megtekintés, http://kgk. uni-obuda.hu/sites/default/files/04_Borbas_Laszlo. pdf

Davies, P. (2000): Student Retention in Further Education: a problem of quality or of student finance? Further Education Development Agency, London.

Jackson C. (2013, szerk.): Az Európai Pályaorientációs Szakpolitikai Hálózat (ELGPN) Szakszótára, ELGPN GLOSSARY. 2014. 01. 06-i megtekintés, http://www.elgpn.eu/publications/browse-by-language/hungarian/az-europai-palyaorientacios-szakpolitikai-halozat-elgpn-szakszotara-elgpn-glossary/

Medway, J. és Penney, R. (1994): Factors affecting successful completion: the Isle of Wight College. Further Education Unit, London.
Meyer, J., Allen, N. és Smith, C. (1993): Commitment to organisations and occupations: extension and test of a three-component conceptualisation, Journal of Applied Psychology, 78. 4. sz. 538-551. DOI: 10.1037//0021-9010.78.4.538

Molnár Beáta (2012): A felsőoktatásban tapasztalható lemorzsolódás lehetséges okai. 2015. 07. 01-i megtekintés, http://www.slideshare.net/molnarbea/ molnr-beta-lemorzsolds-tanulmny?from_action=save

Oliver, R. (1993): Cognitive, affective and attribute bases of the satisfaction response. Journal of Consumer Research, 20. 4. sz. 418-430.

DOI: $10.1086 / 209358$

Polónyi István (2010): Foglalkoztathatóság, túlképzés, Bologna. Educatio, 3. sz. 384-401.

Varga Zsuzsanna (2015): Munkaerő-piaci igényekre támaszkodó gyakorlatorientált képzések, szolgáltatások a Szegedi Tudományegyetem fókuszában. Elöadás, TÁMOP-4.1.1.F-14/1/Konv-2015-0006 Projektnyitó rendezvény, Szeged.

Varga Júlia (2010): Mennyit ér a diploma a kétezres években Magyarországon? Educatio, 3. sz. 370-383. 